Original Paper http://ajol.info/index.php/ijbcs http://indexmedicus.afro.who.int

\title{
Environmental conditions and primary production in a Sahelian shallow lake (Lake Guiers, North Senegal)
}

\author{
Seyni SANE ${ }^{1 *}$, Ngansoumana BA ${ }^{1}$, Robert $\mathrm{ARFI}^{2}$, Papa Ibra $\mathrm{SAMB}^{1}$ and \\ Kandioura NOBA ${ }^{1}$ \\ ${ }^{I}$ Department of Plant Biology, Cheikh Anta Diop University (UCAD), BP 5005 Dakar, Senegal. \\ ${ }^{2}$ Department Environment and Resources, 44, boulevard of Dunkirk, \\ CS 90009, F-13572 Marseille cedex 02, France. \\ *Corresponding author; E-mail: sane.seyni@gmail.com, Tel: +221774399302
}

\section{ACKNOWLEDGMENTS}

This study has been supported by the Research Institute for the Development (IRD) through FLAG program for study the "Determinism of Algal Efflorescence's", in collaboration with Dakar University (UCAD).

\begin{abstract}
This is a study of the environmental conditions and primary phytoplankton production in a Sahelian shallow lake of Senegal, West Africa. Environmental descriptors (nutrient, water transparency, temperature and hydrochemistry) and their effects on primary production were studied. Samples were collected monthly from March 2002 to February 2003 in 3 stations of the central part of water body. Climatic variables show a marked annual pattern following two dominant wind directions: NNE (North-North-East) and NNW (NorthNorth-West). This cyclic evolution affects hydrobiological variables. In this central part of the lake, water body was not stratified with same measures between surface and bottom. Lake water was turbid with lower values during the maritime trade winds period characterized by high water temperatures and conductivity. Water $\mathrm{pH}$ was relatively higher than seven (07) associated with high contents of oxygen (approximately 90\%) in all stations. The station Typha is marked by a low pH and high fluctuations in the rates of oxygen (20 to $120 \%$ ). Nutrient concentrations were low, with high variability (from 0 to $30 \mu \mathrm{g} . \mathrm{l}^{-1}$ for DIN and from 0 to $18 \mu \mathrm{g} . \mathrm{l}^{-1}$ for $\mathrm{PO}_{4}$ ). The primary production in Guiers Lake was high; it showed a vertical gradient with production of $2400 \mathrm{mgC} \cdot \mathrm{m}^{-3}$.days ${ }^{-1}$ in surface and a low of $200 \mathrm{mgC} \cdot \mathrm{m}^{-3}$ days ${ }^{-1}$ at the bottom. In this shallow system, environmental conditions regulate the primary production.
\end{abstract}

(C) 2017 International Formulae Group. All rights reserved.

Keywords: Environmental descriptors, primary production, shallow lake, Senegal.

\section{INTRODUCTION}

Lake Guiers is the largest reservoir of surface water in Senegal. Situated to the north of country, it has a morphology characterized by a northeast and southwest elongation. It is $50 \mathrm{~km}$ length, $7 \mathrm{~km}$ width and has a volume of
680 million $\mathrm{m}^{3}$. It is a shallow flat lake with a depth of $2 \mathrm{~m}$ on average and has a part Northcenter of free water and a south part dominated by the fixed macrophytes, Typha domingensis. Its northern part receives water from Senegal River via the Taoué canal. Its 
level is regulated by the dam of Richard-Toll in the North and Keur Momar Sarr's Dike in the South. This lake plays an important role supplying irrigation water during off-season for instance for off-season sugar production by the Senegalese Sugar Company: CSS. Also, it supplies $45 \%$ of drinking water to the in habitants of Dakar and its neighbourhood, the water processing plants of Ngnith (since 1971) and of Keur Momar Sarr (since 2005). This lake is characterized by a natural functioning marked by a high « anthropisation » and permanent interventions of sea water (Sané et al., 2013). Lake water was regularly salted and the coast fluctuated around a mean value of $0,40 \mathrm{~m}$ (Sané, 2006). With the construction and the starting of dams, Diama anti-salt in 1985 and Manantali in 1987 whose role is to regulate the river floods, the lake functioning became totally controlled. In effect, the salt interventions are stopped. The lake water became permanently sweet and the coastal fluctuations eased (Sané, 2006). The lake average coast is spent in $1.10 \mathrm{~m}$ and is maintained at $2.00 \mathrm{~m}$ since 1996 . These new conditions affected the hydrology (Gac et al., 1993), the hydrochemistry (Cogels and Gac, 1986; Cogels, 1994) and the aquatic vegetation (Cogels et al., 1993) of the lake. The objective of this study was: (1) to describe the dynamic of climatic and hydrobiological variables and (2) to study their impacts on the phytoplankton primary production.

\section{MATERIALS AND METHODS}

\section{Site location}

This study was led in the central part $\left(16^{\circ} 10^{\prime} \mathrm{N}, 15^{\circ} 70^{\prime} \mathrm{W}\right)$ of the lake of Guiers to Ngnith (Figure 1). Situated in the North of Senegal, the lake is fed by the Senegal River via the channel of Taoué. This zone is characterized by a Sahelian climate, with a short rainy season between July and September, marked by very irregular precipitations. The annual rainfall varied between 200 and $250 \mathrm{~mm}$. The level of the lake has been regulated by the dam of Richard-Toll situated on Taoué in the North and the Keur Momar Sarr's dike situated in the South. With a volume about 680 millions of $\mathrm{m}^{3}$, the lake of Guiers supplies until $45 \%$ of drinking water of Dakar, capital of Senegal. This shallow flat lake ( $2 \mathrm{~m}$ on average), 50 $\mathrm{km}$ long and $7 \mathrm{~km}$ wide (surface about 320 $\mathrm{km}^{2}$ ), was subjected to the bidirectional influence of North-East winds (Harmattan) blowing in the main line of the lake from November till May and the northwest (Maritime trade winds) from June till October. The hydrological characteristics and the aquatic and amphibian plant groupings of the site of study were described by Sané et al. (2013).

\section{Samples procedures and analysis}

To study the environment and the primary production of Guiers Lake, a monthly sampling from March 2002 till February 2003 was made in three stations (Table 1) representative of the central zone of the lake. High frequency readings were taken on an hourly scale which allowed for the acquisition of meteorological data of our site.

A Davis Weather station was settled on the bridge of the intake of water intended for the consumption, in approximately $100 \mathrm{~m}$ of the bank and in $3 \mathrm{~m}$ over the water level. It allows the continuous measure of various climatic variables. Air temperature, wind speed (average and gusts), wind direction, precipitation, were recorded hourly during 
March 2002 - February 2003. A Pyranometer (sensor Li-cor 200) is connected with an integrator Li-1000 which recorded (every half an hour) the total irradiance. Water temperature recorders (Onset, Bourne, Massachusetts, USA; precision $0,2{ }^{\circ} \mathrm{C}$ ) which recorded hourly were placed at a depth of $0,5 \mathrm{~m}$ under the surface and $0,5 \mathrm{~m}$ above the bottom in the 3 sampling stations ("Large", "Baie" and "Typha"). The euphotic depth was estimated from coefficient of brilliant extinction $(\mathrm{K})$ values obtained on vertical profiles using a Li-Cor 193 spherical quantum sensor (Poole et Atkins, 1929). Water transparency was estimated using a $30 \mathrm{~cm}$ diameter Secchi disk. Vertical profiles of temperature (precision $0.01{ }^{\circ} \mathrm{C}$ ), conductivity (precision $0.01 \mu{\mathrm{S} . \mathrm{cm}^{-1}}^{\text {) }}$ and dissolved oxygen were recorded (all 0.5 second) using a Sea Bird CTD recorder (SBE 19).

Water samples for $\mathrm{pH}$, dissolved inorganic nutrient and chlorophyll $a$ determination, were collected using a PVC tube $(3.5 \mathrm{~cm}$ diameter, $2 \mathrm{~m}$ length) with 2 separate compartments immersed vertically to obtain an integrated sample of the water column: at 0 to $1.5 \mathrm{~m}$ and 1.5 to $2 \mathrm{~m}$ for the deeper stations ( $\mathrm{L}$ and $\mathrm{B}$ ), and at 0 to $0.5 \mathrm{~m}$ and 0.5 to $1 \mathrm{~m}$ for the shallower $(\mathrm{T})$. Water from each compartment (« surface » and « bottom ») was then stored in 1.5 litre polycarbonate bottles up to analysis in the laboratory. $\mathrm{pH}$ was measured with a WTM 320/SET pH-meter. Chlorophyll $a$ concentrations were determined on glass fibres membranes (Whatman GF/F) loaded with particles. It is a fluorimetric measure based on the fluorescence of the chlorophyll extracted in cold during 45 minutes in some pure methanol (Holm-Hansen et al., 1965).
Samples for dissolved inorganic nutrient (N.NO $\mathrm{N}_{3}, \mathrm{~N} . \mathrm{NH}_{4}$ and P.PO P $_{4}$ dosage was previously filtered under glass fibre membrane (Whatman $\mathrm{GF} / \mathrm{F}$ ), then the filtrate fixed by mercuric chloride $\left(\mathrm{HgCl}_{2}\right)$ addition and analyzed according to the procedures described by Strickland and Parsons (1972).

The primary production was determined using the radioactive carbon $\left({ }^{14} \mathrm{C}\right)$ assimilation by algae. Water samples were incubated with radioactive carbon solution, and then filtered on glass fibre membrane (Whatman GF/F). The filters loaded with particles was dumped during 24 hours in a twinkling liquid " Ready Safe ». The radioactive carbon assimilated was estimated by ${ }^{14} \mathrm{C}$ fluorescence measured on Beckman LS 500 sparkle meter.

\section{Statistical analysis}

The various data were statistically analyzed by adopting a parametrical approach when the distribution is normal and when the variances are equal or an approach not parametrical when the opposite occurs. Within the framework of the parametrical approach, the variations between stations were tested by the analysis of variance (One Way ANOVA) for a comparison of more than two averages or the test of Student Newman-Keuls (T-test) for a comparison of two averages. Within the framework of the approach not parametrical, the variations were tested by the test of Kruskal-Wallis in One factor (more than two averages) or the test of Mann-Whitney (two averages). In every case, tests parametrical and not parametrical, the differences were considered significant when the probability was lower than $5 \%(\mathrm{p}<0.05)$. 
Table 1: Sampling stations, their morphology and geographical location.

\begin{tabular}{lcccc}
\hline \multicolumn{1}{c}{ Station designation } & Sediment or Bottom & Depht $(\mathbf{m})$ & \multicolumn{2}{c}{ GPS location } \\
\cline { 3 - 5 } & & & North & West \\
\hline Large (L) & Sablo-Muddy & 2.7 & $16^{\circ} 09^{\prime} 28^{\prime \prime}$ & $15^{\circ} 52^{\prime} 57^{\prime \prime}$ \\
Baie (B) & Muddy & 2.3 & $16^{\circ} 12^{\prime} 24^{\prime \prime}$ & $15^{\circ} 53^{\prime} 10^{\prime \prime}$ \\
Typha (T) & Muddy with roots & 1.3 & $16^{\circ} 11^{\prime} 15^{\prime \prime}$ & $14^{\circ} 54^{\prime} 13^{\prime \prime}$ \\
& of macrophytes & & & \\
& & & & \\
\hline
\end{tabular}

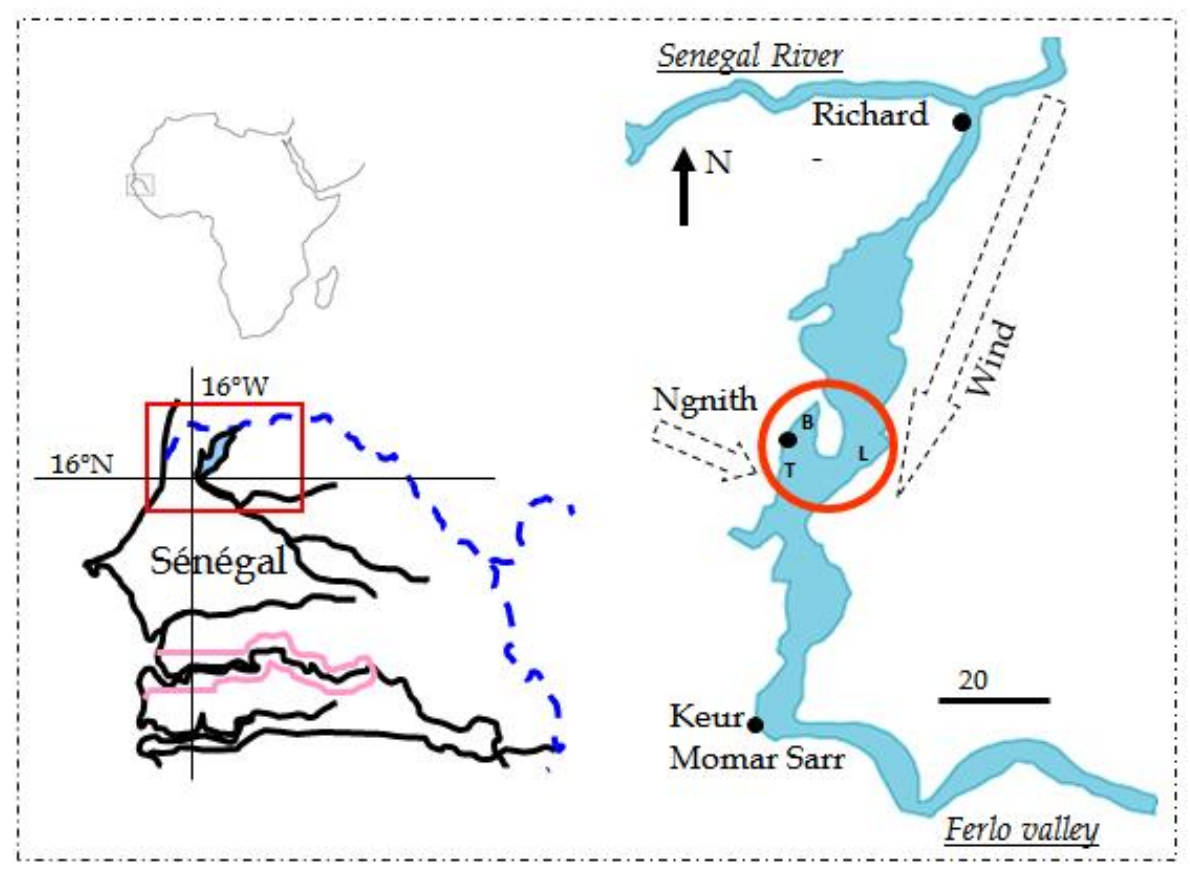

Figure 1: Map of Guiers Lake showing position of sampling stations (table 1 for corresponding stations names).

\section{RESULTS}

\section{Climatic variables}

The various climatic variables were represented on ten daily weather: average for the temperature, the wind speed and ads for the rains, the solar radiation (Figure 2). The breaks on graphs correspond to data loss. The precipitations were essentially concentred between June and October. During this rainy period, the precipitations for ten days were less than $25 \mathrm{~mm}$. Rain rarely exceed $10 \mathrm{~mm}$ day $^{-1}$ except for one particular high observed on September $12^{\text {th }} 2002(17 \mathrm{~mm})$. Traces of rains (1-2 mm) were logged during 
the study. The rain events were generally short (1-3 h) and violent, often corresponding to storms. With a total of $122 \mathrm{~mm}$.year ${ }^{-1}$, these rains were lower than observed in two close localities, Louga (222 mm.year $\left.{ }^{-1}\right)$ and SaintLouis $\left(230 \mathrm{~mm}_{\text {.year }}{ }^{-1}\right)$. The air temperature followed a marked annual pattern. The lower values $\left(22-26{ }^{\circ} \mathrm{C}\right.$ daily on average) were observed from November to May and the high $\left(28-32{ }^{\circ} \mathrm{C}\right)$ from June to October 2002 . Those high values were observed during the raining period, showing the low effect of rain in temperature sinking. The low temperatures were noted during the dry season, and the lower corresponding to November at February 2003. The wind direction reflects the bidirectional influence of the trade wind (harmattan and marine trade winds). From November to May, the wind blew from the $\mathrm{NE}$ and corresponds to the Harmattan. May was a transitional month when the wind changed direction and become NW from June to October. This second period was marked by the influence of monsoon, wind blowing from SE. The wind speed showed a cyclical annual pattern as compared with the dominant direction of winds. The high wind speeds were observed in harmattan conditions (4$\left.5 \mathrm{~m} \cdot \mathrm{s}^{-1}\right)$. The lower values were observed in marine trade wind and monsoon conditions $\left(<4 \mathrm{~m} \cdot \mathrm{s}^{-1}\right)$. During the study, the daily average wind speed rarely exceeded $6 \mathrm{~m} . \mathrm{s}^{-1}$ and the high value was observed on April $25^{\text {th }}$ $\left(6.3 \mathrm{~m} \cdot \mathrm{s}^{-1}\right)$. The wind speed showed an important fluctuation with values between 0 and $11.2 \mathrm{~m} \cdot \mathrm{s}^{-1}$ (as the registered maximum). Solar radiation showed a progressive decrease during the study. The high value (80000 Wh.m ${ }^{-2}$ ) was recorded in April 2002 and the lower $\left(20000 \mathrm{Wh} . \mathrm{m}^{-2}\right)$ in February 2003. The daily sum of solar radiation exceeds regularly $5000 \mathrm{Wh} . \mathrm{m}^{-2}$ in large part of the study. The lower values were observed in winter with 973 Wh.m ${ }^{-2}$ logged in December $09^{\text {th }} 2002$.

\section{Water level}

From March to June the lake water level remained stable at $2.1 \mathrm{~m}$ (Figure 3). In July, an important fluctuation was observed between 2 and $2.2 \mathrm{~m}$. Water level decreased rapidly from August reaching about $1.8 \mathrm{~m}$ in September 2002. A progressive increase was observed until December, and the water level became stable. The decreasing of water level beginning in August was linked to water flow towards Ferlo valley. This period of low water level corresponds to the flood of Senegal River. Beginning in July, the flood maximum was reached in September $\left(1400 \mathrm{~m}^{3} \cdot \mathrm{s}^{-1}\right)$ and decreased by November 2002. But the influence of flood in Lake water level was highlighted in the time; as in 2002 when the communication between lake and Senegal River produced in September.

\section{Water transparency}

The water transparency measured (Secchi disk transparency) increased from March (0.6 m) to July ( $0.9 \mathrm{~m})$, and sink to the end of study $(0.5 \mathrm{~m})$ for all the 3 stations (Figure 4). The light attenuation coefficient showed an inverse evolution. The values were decreased from March to July-August, and increased in September to the end of study. A marked annual pattern was observed in the two stations («Large» and «Baie»), and not significant in «Typha» station. In the «Large» station, a high value $\left(3.0 \mathrm{~m}^{-1}\right)$ was measured in March. In stations «Baie» and «Typha», these high values were observed in December $\left(2.6 \mathrm{~m}^{-1}\right)$ and in September $\left(3.6 \mathrm{~m}^{-1}\right) 2002$ respectively. The euphotic layer depth was calculated using the relation with light attenuation coefficient $(\mathrm{Ze}=4.605 / \mathrm{K})$, data not shown. The euphotic layer depth showed the 
same evolution as water transparency by Secchi disk. An increase from March to July, and a decrease to the end of study was observed. The euphotic layer depth average exceeds $2 \mathrm{~m}$ during the study, and lake depth average was $2 \mathrm{~m}$. The euphotic layer depth also represents $100 \%$ of the water body.

\section{Water temperature}

The water temperature recorded in the 3 sampling stations followed a marked annual pattern (Figure 5). The surface and bottom water temperature were closely correlated to the air temperature $(r>0.8$ with $\mathrm{p}<0.0001$, respectively: Pearson correlation test). The seasonal chance of air mass directly affects thermal characteristics of the water body. Effect of air mass was noted until the bottom. Water temperature was low during the harmattan conditions with lowest values $\left(19^{\circ} \mathrm{C}\right)$ observed in January 2003 . The marine trade wind condition was marked by an increase of water temperature with high value (about $32{ }^{\circ} \mathrm{C}$ in September at Typha sampling stations). In the 3 sampling stations, no thermal stratification was observed. A low difference between surface and bottom was noted only in harmattan conditions especially from November to February, with a difference $\sim 2{ }^{\circ} \mathrm{C}$.

\section{Hydrochemistry}

Water conductivity (surface and bottom) followed the same evolution in the 3 sampling stations (Figure 6a). No difference was observed between surface and bottom conductivity (student t-test : $\mathrm{p}>0.05$ ). From the beginning of the study in July 2002, water conductivity was relatively stable with values between 180 and $190 \mu \mathrm{S} . \mathrm{cm}^{-1}$. Water conductivity increased until September with high values $\sim 210 \mu \mathrm{S} . \mathrm{cm}^{-1}$, and decreased to the end of study $\left(\sim 150 \mu{\mathrm{S} . \mathrm{cm}^{-1}}^{-1}\right.$. pH (Figure 6b) showed a regularly increasing trend during the study in the 2 sampling stations (Large and Baie). From 7.0 at the beginning, $\mathrm{pH}$ values reach 9.0 at the end of study. In Typha sampling station, $\mathrm{pH}$ values increased from March to September-October 2002, and decreased to the end of study. In this sampling station, the high and low values of $\mathrm{pH}$ were less than observed in the two other sampling stations. Thus, a significant difference was observed between Typha sampling station and the two other sampling stations (ANOVA: $\mathrm{p}=0,003$ ). For all the sampling stations, no difference was observed between water $\mathrm{pH}$ in the surface and bottom (student t-test: $\mathrm{p}>0.05$ ). Water oxygen was represented by the percentage saturation (Figure 6c). In both sampling stations (Large and Baie), a low fluctuation was observed during the study with values between 80 and $110 \%$. A large fluctuation was observed in Typha sampling station with values between 30 and $130 \%$. The surface and bottom values were relatively similar in both sampling stations (Large and Baie). In Typha sampling station, a space of $50 \%$ was observed from September to December 2002.

\section{Nutrient}

During the period of study, ammoniac represented an important portion of the DIN (Dissolved Inorganic Nitrogen). $\mathrm{NH}_{4}-\mathrm{N}$ contribution to the DIN represented in average 60 to $80 \%$. In the 3 sampling stations, DIN concentrations followed a marked annual pattern (Figure 7a) in the surface and the bottom. From March to May, the DIN concentrations increased to reach high values of $30 \mu \mathrm{g} .1^{-1}$ in the surface (Large), and 25 $20 \mu \mathrm{g} .1^{-1}$ respectively in sampling stations Baie and Typha at the bottom. A rapid break was observed until in August with the lower values $\left(2 \mu \mathrm{g} . \mathrm{l}^{-1}\right)$. The DIN concentrations 
increased then slightly to reach $15 \mu \mathrm{g} .1^{-1}$ at the end of study. The $\mathrm{PO}_{4}-\mathrm{P}$ concentrations showed an important fluctuation during the study. The same evolution was observed between surface and bottom in the 3 sampling stations (Figure $7 \mathrm{~b}$ ). In all sampling stations, $\mathrm{PO}_{4}-\mathrm{P}$ concentrations vary from 0 to the high values $18 \mu \mathrm{g} .1^{-1}$ (Large), $15 \mu \mathrm{g} . \mathrm{I}^{-1}$ (Typha) and $10 \mu \mathrm{g} . \mathrm{l}^{-1}$ (Baie). In all of nutrient values, no significant difference was observed between those 3 sampling stations $(\mathrm{p}>0,05)$.

\section{Primary production}

The primary production did not follow an annual pattern in the 3 sampling stations (Figure 8). But from March to July, primary production covered practically all the water column (between $0-1.5 \mathrm{~m}$ of depth). From August to the end of study, the primary production decrease according to the depth. The essential of production was concentred between $0-0.5 \mathrm{~m}$ with values $>1000 \mathrm{mgC} . \mathrm{m}^{-}$ ${ }^{3}$.days $^{-1}$. The month of September with the lower depth of the lake was marked by a primary production between $200-800 \mathrm{mgC.m}{ }^{-}$ ${ }^{3}$.days ${ }^{-1}$. During the study, primary production varied between $100 \mathrm{mgC} \cdot \mathrm{m}^{-3} \cdot$ days $^{-1}$ in September (near the bottom) and $2500 \mathrm{mgC} \cdot \mathrm{m}^{-3}$.days $^{-1}$ in March (near the surface). The lower values were observed in the Large sampling station $\left(100 \mathrm{mgC} . \mathrm{m}^{-}\right.$ ${ }^{3}$.days ${ }^{-1}$ near the bottom and $2080 \mathrm{mgC} . \mathrm{m}^{-}$ ${ }^{3}$.days ${ }^{-1}$ near the surface).
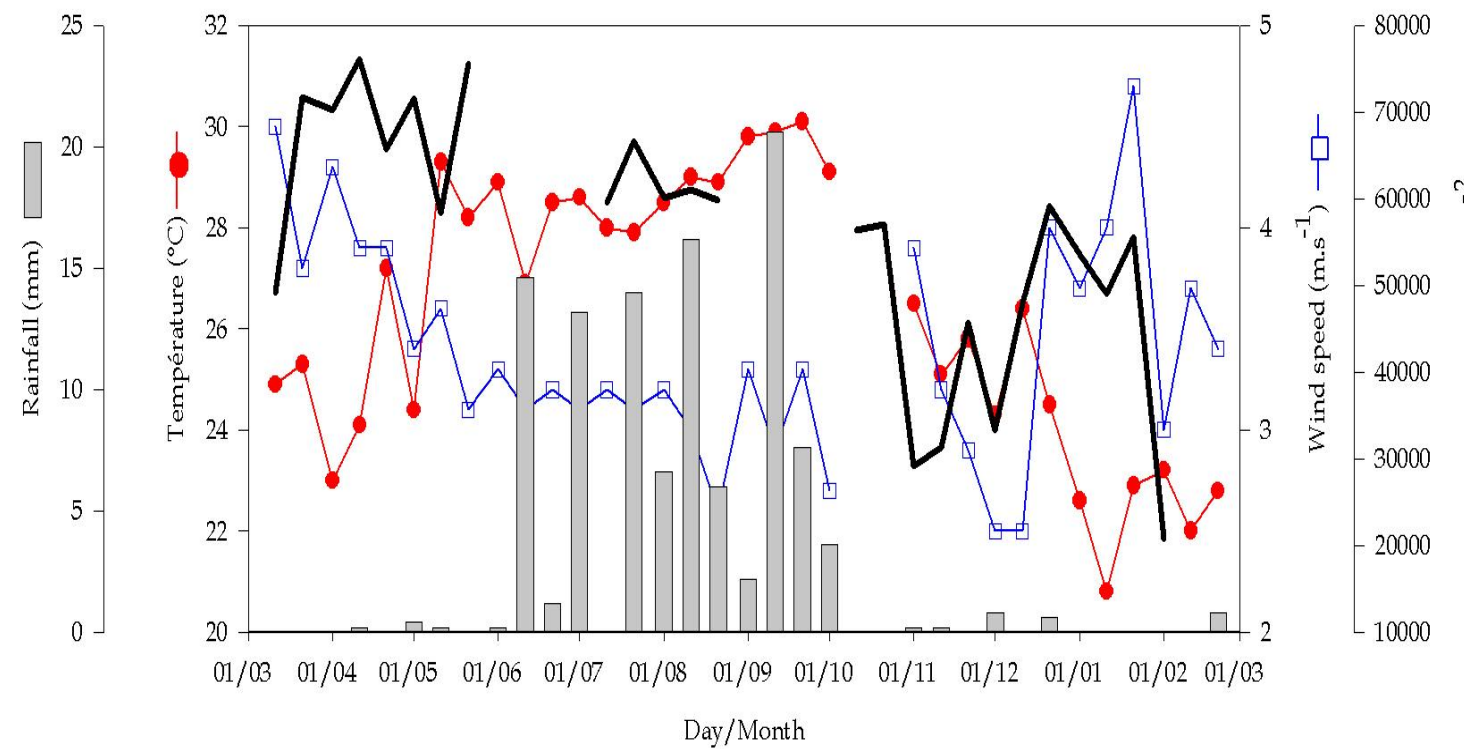

$$
\text { Day/Month }
$$

Figure 2: Weather conditions recorded at Guiers Lake during the study: average (temperature and wind speed) and sum (rainfall and solar radiation) on ten daily weather. 


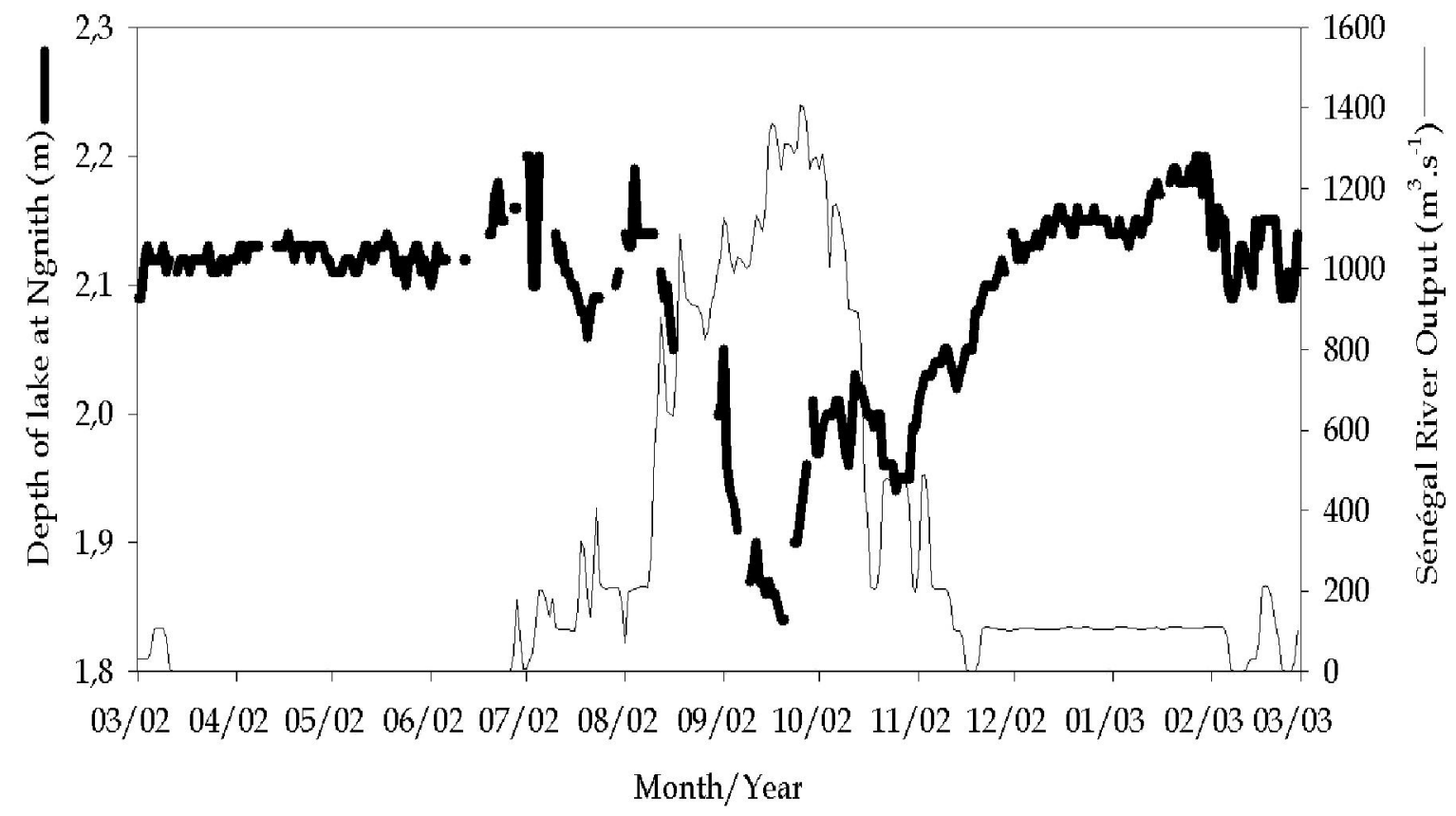

Figure 3: Daily time series of lake depth at Ngnith and Senegal River flow during the study.
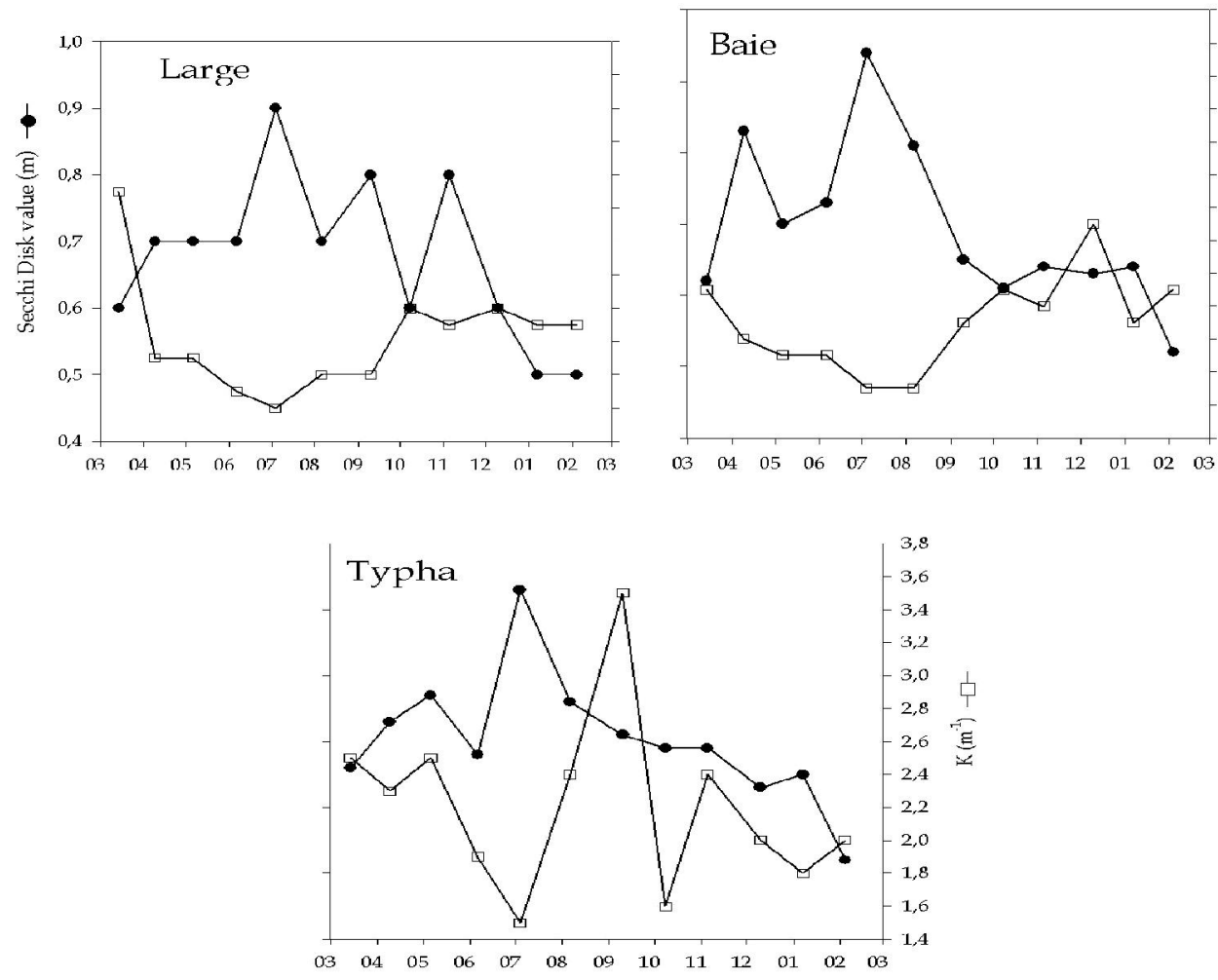

Figure 4: Annual variation of transparency by Secchi Disk and the light attenuation coefficient, in the 3 sampling stations. 

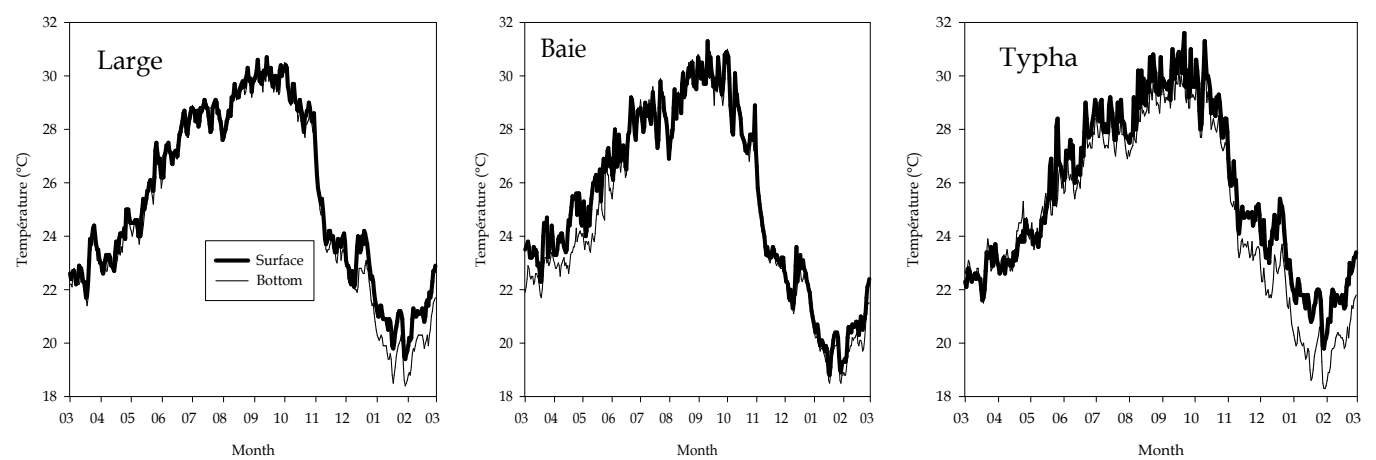

Figure 5: Annual variation of water temperature in the 3 sampling stations (thick and finer line refer to the surface and bottom level).
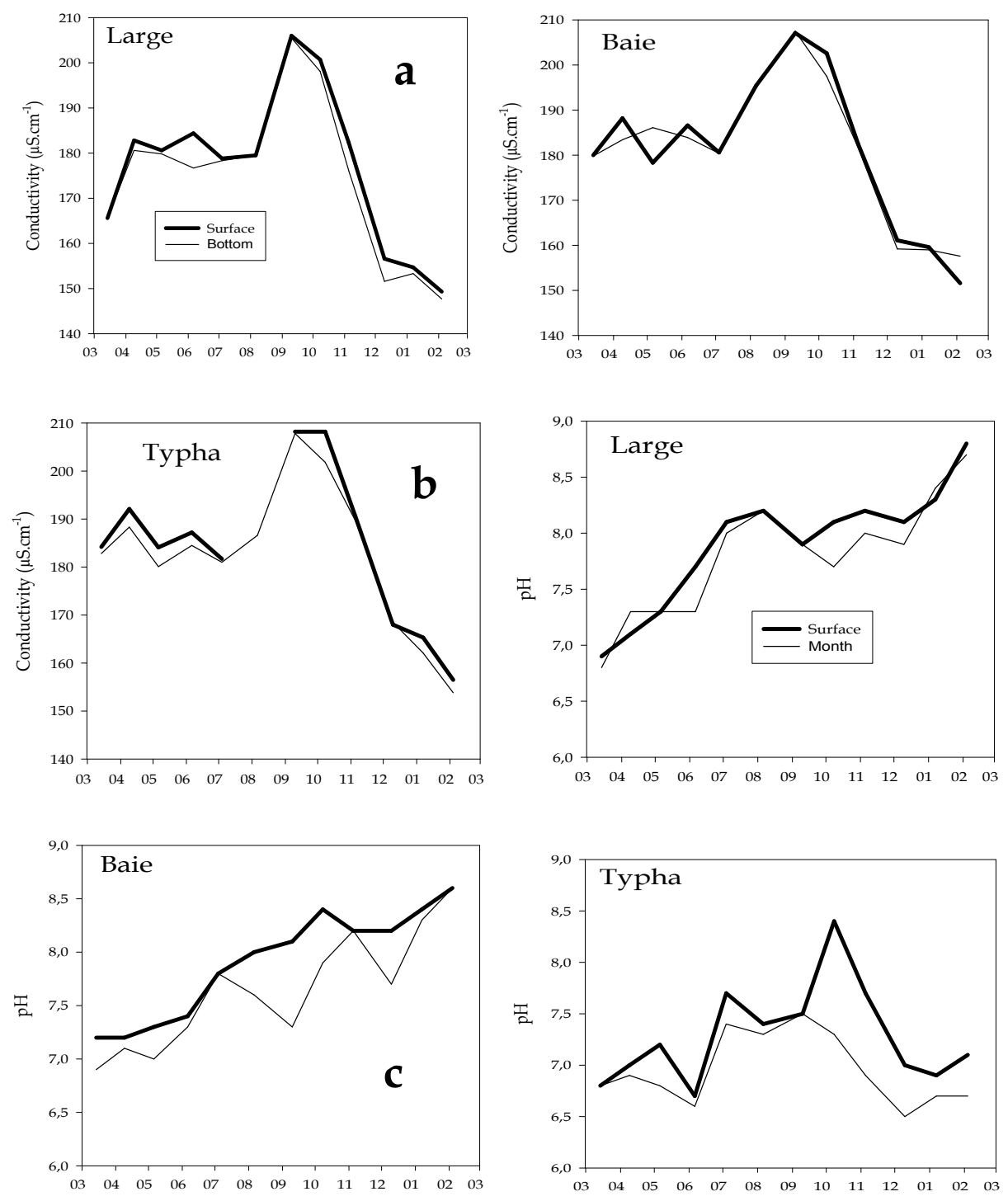

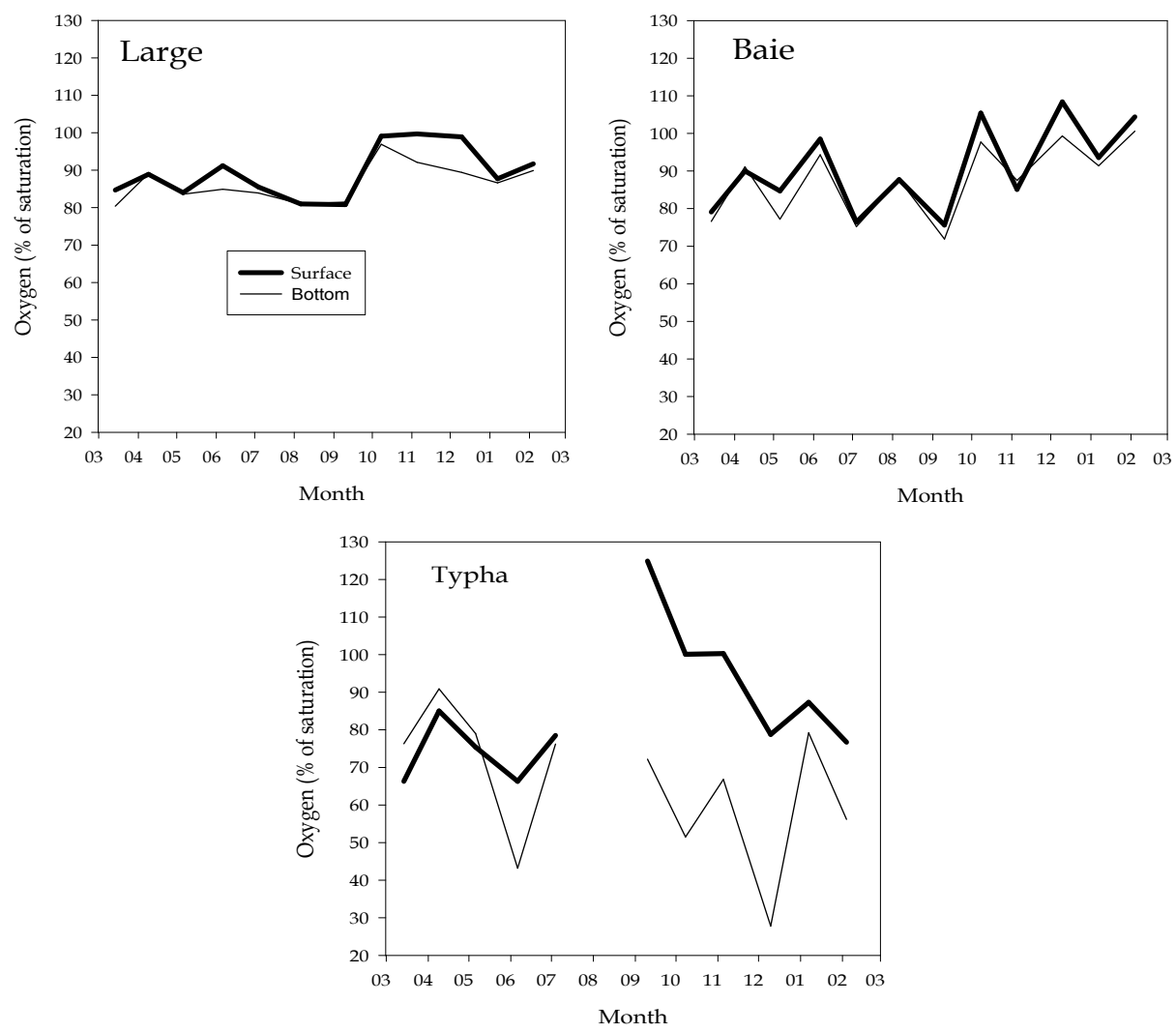

Figure 6: Annual variation of hydrochemistry descriptors in the 3 sampling stations: a) for the conductivity, b) for the $\mathrm{pH}$ and $\mathrm{c}$ ) for the water oxygen in percentage saturation.

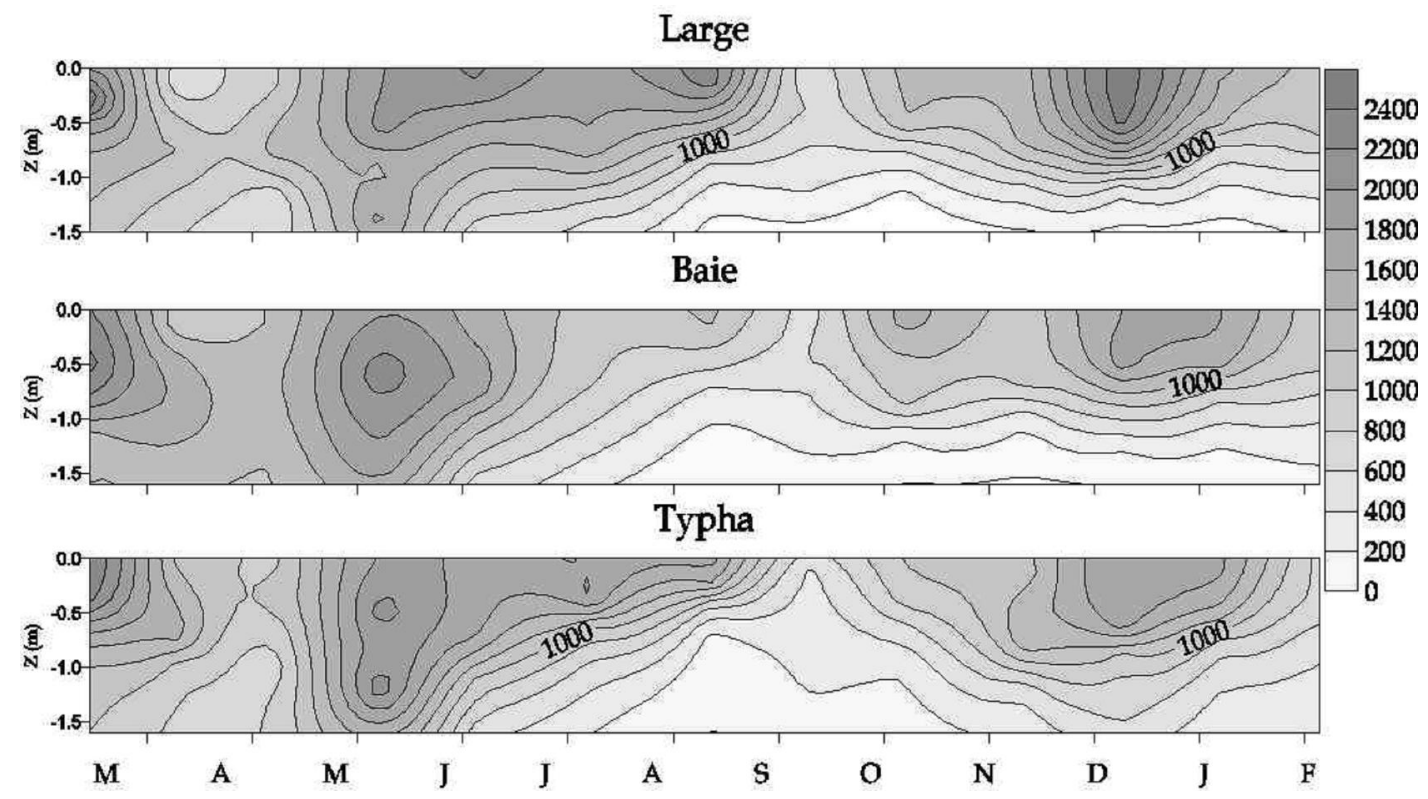

Figure 8: Annual variation of primary production $\left(\mathrm{mgC} \cdot \mathrm{m}^{-3} \cdot \mathrm{d}^{-1}\right)$, according to the depth in the 3 sampling stations. 

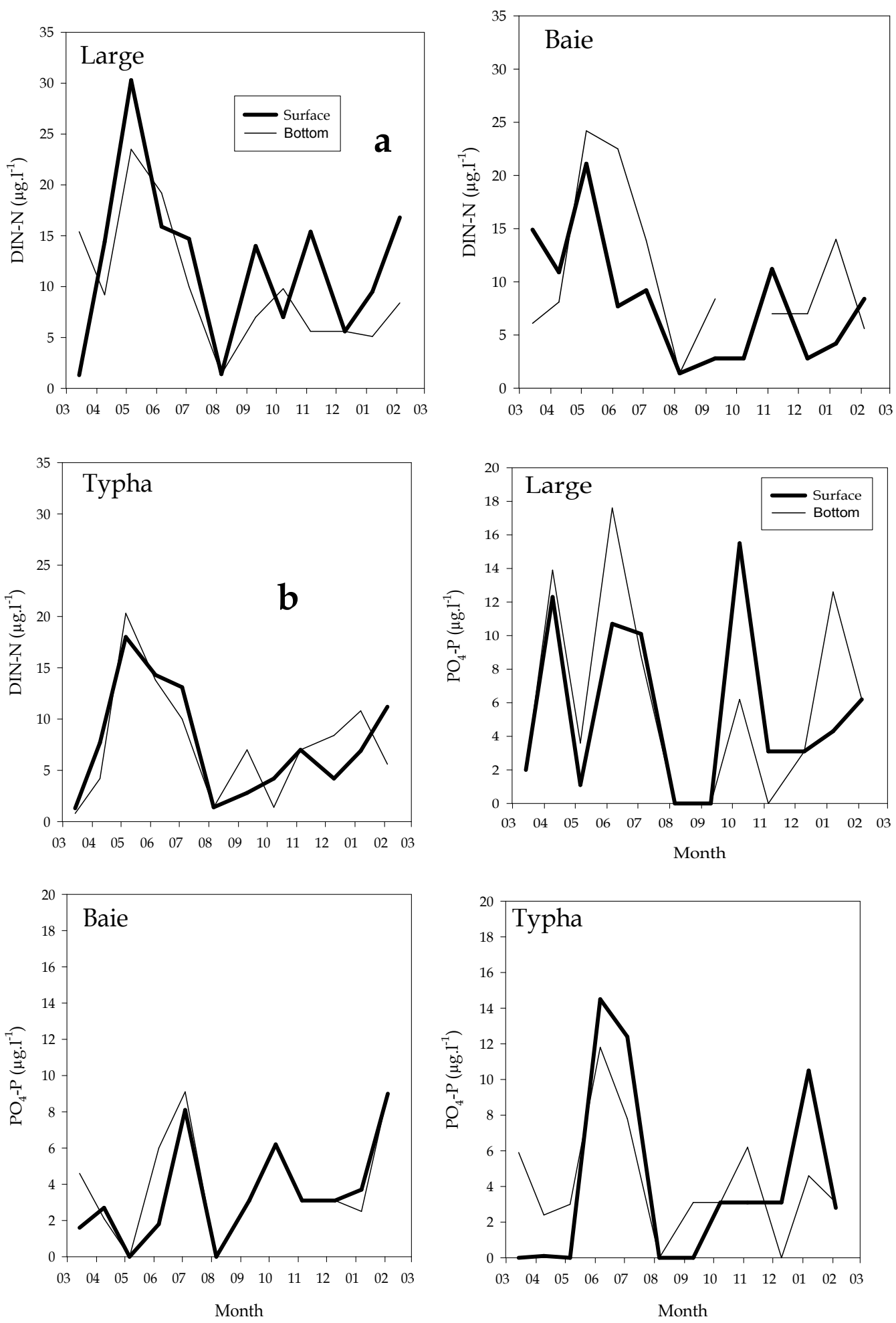

Figure 7: Annual variation of nutrient in the 3 sampling stations: a) for DIN and b) for PO4-P 


\section{DISCUSSION}

\section{Climatic conditions and water temperature}

Sahelian zones climate is marked by a long dry season (which covers the winter) followed by a short rainy season. Rains are concentrated between June and September with lower recorded during the study period. The rainy period is marked by the simultaneous influence of Oceanic winds and monsoon. These winds have low speed (average, $3 \mathrm{~m} \cdot \mathrm{s}^{-1}$ ) compared with northeast trade winds (harmattan). Harmattan influence is important by its force (average, $5 \mathrm{~m} . \mathrm{s}^{-1}$ ), and by the dust which it transports during its passage through the Sahara desert (Kalu, 1979, Goudie et Middleton, 2001). Air temperature differences during these two periods were pronounced. The low temperature observed during the long dry season is due to the presence of sand dusts, which invade the zone but also in the decline of the sun's brilliance (Lavaysse et al., 2011; Moulin et al., 1997). Indeed, the Saharan desert influence contributes to the reduction of air temperature by absorption and dispersal of sun radiation (Lavaysse et al., 2011; Alpert et al., 1998). The air temperature evolution was classic for this zone, as comparable results were observed by Arfi (2003) in Selingue Lake (Mali). However, the ten daily weather representations summarize true values. Indeed, air temperature fluctuated between 12 and $42{ }^{\circ} \mathrm{C}$ and the amplitude was comparable to temperate zone as Creteil Lake (Garnier, 1989) in Paris region. Air temperature evolution affected water one. A positive correlation was observed between air and water temperatures. This can be due to a homogeneous distribution of sun radiations in the entire water column. Thus, the seasonal change of air mass directly affected the thermal characteristics of the water column. However, seasonal temperature fluctuations (18-32 $\left.{ }^{\circ} \mathrm{C}\right)$ were less than those of the air temperature. These extreme values are comparable with those observed by a group of experts (Carl Bro International, 2000). According to these authors, water temperature is favorable for good productivity of phytoplanktons. The annual amplitude, twice as low as that of the air temperature, is however comparable with that of Lake Chad (Carmouze et al., 1983). The low depth of Guiers Lake does not allow a thermic stratification (Sané, 2006). But, the sun radiations allow surface water reheating with regard to that of the bottom.

\section{Hydrologic conditions}

Since the construction works on the Senegal River (Diama dam in 1985 then that of Manantali in 1987), the functioning of the lake became totally controlled (Sané et al., 2013). The communication river and lake was made at the beginning of July and had reached its maximum in September. During flood periods, the lake was marked by a decline of water level. This paradoxical evolution can be linked to a shift phase between entrance and exit of lake water. In addition, before every river flood, a part of lake water was evacuated to the South towards the low valley of Ferlo. This water evacuation to low valley of Ferlo had begun since 1987 (Cogels et al., 1993). This process contributed to the elimination of a great quantity of mineralized water. Communication between river and lake occurred during floods (in September). However, if evacuation of water from the lake is fast, it takes more time for lake water to return to its normal level. The lake level remains relatively constant during a large part of the year with an average coast of $2 \mathrm{~m}$. This decline of the fluctuation in the level of the lake was gradually made after the construction works in the river and the lake. Before construction, lake level highly fluctuated 
during hydrological cycle (Cogels et al., 1993; Sané, 2006).

Water transparency evolution is especially linked to the event of wind and to the particle dynamics, thus the phytoplanktons (Figure 4). The high transparency can be linked to an important sinking of particles. The results of the cellular counting ( $\mathrm{Ba}, 2006)$ showed that the phytoplankton is dominated by Diatomeae with genre Fragilaria. Indeed, these algae endowed with a heavy siliceous envelop tend to sink when the wind speed decreases. This situation was observed especially when the Oceanic winds dominate. Their northwest direction implies a low fetch, what does not favour the resuspension led by waves (Sané et al., 2015). The transparency increase especially in July is linked to the low resuspension which was translated by a seston and a biomass phytoplanktonic low (Sané, 2006). In situation of high wind (harmattan), winds blow in the main line of the lake. The important fetch is translated by the waves forming whose intensity is proportional to the distance in which the wind blows in the same direction (fetch). Particles are then strongly resuspended, pulling water turbidity, thus a low transparency. The Secchi measures were lower than $1 \mathrm{~m}$ over all the period of the study and in three sampling stations. Comparable results were observed in five shallow lakes (2$2.5 \mathrm{~m}$ depht) of Asia with Secchi lower than 1 $\mathrm{m}$ (Hasan et al., 2001). On the other hand, different results are observed in Selingue Lake of Mali (Africa), with average Secchi of $2.4 \mathrm{~m}$ (Arfi, 2003). In this reservoir, the concentrations in chlorophyll $a$ are comparable with those recorded in our site. But the high transparency was linked to the highest depth which is $5.3 \mathrm{~m}$ on average.

Conductivity evolution seems to be influenced by that of water temperature but also by that of wind speeds and directions. The ACP analysis allowed grouping of various hydrobiological variables according to oceanic winds and harmattan periods (Sané, 2006). Thus, during the period of strong heat (Oceanic winds), waters are less dense but have a high conductivity. The situation is reversed when the temperatures fall, what is observed during harmattan period. The maximal water conductivity in this central zone of lake $\left(210 \mu \mathrm{S} . \mathrm{cm}^{-1}\right)$ is twice less brought up than that observed in 1979 (500 $\mu \mathrm{S} . \mathrm{cm}^{-1}$ ) by Dia and Reynaud (1982). The current significant decline of water conductivity interacts with the starting of Diama anti-salt dam which prevents the salt ascent in the river since 1985, and thus the salt interventions in the lake. However, the water conductivity is larger than observed at Selingue Lake in Mali (Arfi, 2003).

\section{Chemical conditions}

Water $\mathrm{pH}$ increases whereas the concentrations of nutriment remain low and a spatial evolution is observed. The Typha station dominated by the macrophyte (Typha domingensis) distinguishes itself by waters with $\mathrm{pH}$ lower than other stations. Indeed, in this last station, the humic acid which results in the decomposition of the dead macrophytes contributes to significantly lower $\mathrm{pH}$ levels. But the average $\mathrm{pH}$ of water in this central part of lake is as that observed previously by Dia and Reynaud (1982). This average $\mathrm{pH}$ is, besides, comparable with that of some waters of rivers Gambia (Lô, 1984) and Senegal (Cogels, 1994) and of Selingue Lake in Mali (Arfi, 2003).

Oxygen is expressed in percentage of saturation. In this shallow environment, the regular mixture of water column allows good oxygenation. The lake bottom is well oxygenated with average percentages comparable with those of the surface. This situation would be favourable to the preservation of an important biomass of 
microphitobenthies algae. The station Typha was marked by a distance between surface and bottom oxygen which can reach sometimes $50 \%$ during the period from September till December. In this central part of lake, very rare oversaturation was linked to an important immobilization of oxygen by the vegetable biomass. Indeed, with the permanent preservation of lake fresh water, macrophytes and microphytes are strongly developed (Sané et al., 2013). But also, an important part of oxygen is used by a high biomass bacterium on average to the order of $10^{7} \mathrm{ind}_{\mathrm{ml}} \mathrm{m}^{-1}$ (Bouvy, 2002. Not published). In this dynamic characterized by an increasing phytoplanktonic biomass since 2002 (Sané, 2006), oxygen well sought well. The environment becoming more and more eutrophe, it is going to be translated by a decline of the available contents in oxygen for the other bodies.

Nutrient salts are represented by the nitrogen and the phosphorous which enter in the metabolic cycle of vegetables. In the aquatic systems, the origin of these nutrients can be multiple. An exogenous origin marked by the streaming of rainy waters on the continent which transport nutrient stemming from the re-mineralization of the ground vegetables (Thomas, 2000). Or by the first rains which wash an atmosphere rich in dust (Lemoalle, 1973) but also by the anthropological contributions discharges of waste water etc. An internal origin can result from the mineralization of the organic matter stemming from algae and from dead aquatic macrophytes (Goldsborough and Robinson, 1996). On Guiers Lake, these nutrients result from a continuous contribution constituted by the various discharges of the factories of SDE (Senegalese Of Waters) and of CSS (Senegalese Sugar Company) and waters draining the surfaces of the irrigated cultures. But also of a limited time contributions, it is the case of Saharan dusts (period of harmattan) that contain considerable quantities (Swap et al., 1992; Goudie and Middleton, 2001) of rain waters and of Senegal River floods. This last source can be important. Indeed, during the floods of 2002, the concentrations of phosphor $\left(\mathrm{PO}_{4}\right)$ and inorganic nitrogen $\left(\mathrm{NH}_{4}\right.$ and $\left.\mathrm{NO}_{3}\right)$ upstream the rivers are low with respective values of 0.1 $\mu$ mol. $1^{-1}$ and $2.3 \mu \mathrm{mol}^{-1}{ }^{-1}$ (Sané et al., 2013). On the other hand, they were multiplied by eight in the river and in the lake entrance. A big part of these nutrients thus results from waters streaming draining the surfaces of the irrigated cultures which developed well along the river. But during their transit in Taoué channel (17 km long) and the north zone of the lake, these nutrients were partially likened by macrophytes floats and phytoplankton development. The contributions of nutrients by the rain are low and linked to the small rain recorded (maximum lower than $18 \mathrm{~mm} \cdot \mathrm{j}^{-1}$ ). The importance of nutrients contributions by rainy waters was reported in several tropical hydrosystems of Guinea Golf (Lemasson and Pages, 1982), of Tanganyika Lake (Langenberg and Nyamushahu, 1997), of Northern Nigeria River (Goni et al., 2001) and of Selingue Lake (Arfi, 2003). The high quantities of rain come along with important concentrations of nitrogen and phosphorous. During our study, the concentrations of nutrients were low and the main part was represented by ammonium. A big part would be immobilized in an important phytoplanktonic biomass (Sané, 2006). But in this lake where the interface water-sediment is well oxygenated, immobilization of phosphorous in the sediment as well as the denitrification also contributes to decrease in nutrient rates. Barroin (1985) and Labroue et al., (1988) underlined the importance of the de-nitrification process in the shallow environment, as Guiers Lake. However, these 
nutrient concentrations were raised compared with those previously noted by Cogels (1994) and by Carl Bro International (2000). The increase in the nutrients is related to the consecutive important contributions with extension of surfaces of irrigated cultures since permanent sweetening of river and lake water; but also with an increase in the various domestic and industrial wastes. This increase of nutrients came along with an increase of the algae biomasses which play a role of control. This control is also exercised by the macrophytes biomass which is more or less important since the sweetening and the stability of the lake waters. Studies of Sarr et al. (2001) allowed to list 16 main species of macrophytes. They are organized around five plant groupings: Typha domingensis, Pistia stratiotes, Paspalidium geminatum, Scirpus littoralis and Potamogeton octandrus. These macrophytes can thus enter competition with the phytoplankton for nutrient assimilation. However, Typha domingensis who dominate the populating of macrophytes develop well on the coast of the lake. This last one is capable of assimilating the nutrients which are as well in the sediment as in the water column (Wetzel, 2001) would contribute partially more important for the immobilization of nutrients. However, results showed that nutrient concentrations in the zone of typhas (station $\mathrm{T}$ ) were identical to those of the zone of free water (stations L and B). The presence of these fixed macrophytes reveals little seems to influence the imbalance of the concentrations of nutrients with regard to the part of free water.

\section{Effects of physico-chemical variables on the primary production}

Solar light constitutes a factor determining primary production of phytoplanktons. In tropical environments, the light does not constitute a brake in the photosynthetic activity because it exists in sufficiency. But its fluctuation during a period can influence the rate of inorganic carbon assimilation by the autotrophic zone. During the study, evolution of volumetric production was made in two phases. Throughout the first phase (from March to July), the production was dominant through the water column. In the second phase (August to the end of study), the essential production was made at the level of the first 500 centimeters. This difference can be attributed to the effect of wind which pulls a mixture more or less different from the water column. The phytoplankton primary production in this central part of the lake is raised (Sané, 2006). The values are comparable to those observed in the other tropical hydrosystems, notably the reservoirs of Brobo and Nambengué (Arfi et al., 2003) in Côte d'Ivoire, the Chad Lake in Niger (Barbosa and Tundisi, 1980). The Guiers Lake is eutrophic (Sané et al., 2013). However, these values of primary production are widely lower than that of eutrophic reservoirs as Bakarivogo, Dikodougou and Poundia in Côte d'Ivoire (Arfi et al., 2001). This primary production is realized by a very diverse alga. In this central part of lake, seven classes of algae were identified and dominated by cyanophyceae and the chlorophyceae which occupy, in all, more than $50 \%$ of the species met (Ba, 2006; Sané et al., 2013). Previous studies realized in this Guiers Lake (Dia and Reynaud, 1982; Compère, 1991; Carl Bro International, 2000) reported prevalence of these two classes in aquatic systems of western Africa. In Burkina Faso lakes, works of Baijot et al. (1994) showed prevalence of cyanophyceae in eutrophes sites and chlorophyceae in mésotrophes sites. In Nigerian ponds (Khan, 1987) and in Côte d'Ivoire (Dabbadie, 1996), dominance of chlorophyceae and cyanophyceae, accompanied sometimes with a weak number 
of diatomeae (bacillariophyceae), was revealed. However, total size of individuals was dominated by the classes of cyanophyceae and bacillariophyceae (Sané et al., 2013). These two classes which represent more than $80 \%$ of the total size have an annual evolution characterized by the alternation of the prevalence of a class or the other one, according to the period of the year (Ba, 2006). This evolution would be linked to their physiological characteristics. In harmattan situation, bacillariophyceae is handed in suspension under the effect of winds which present higher speeds. Furthermore, the lower temperatures of water are favorable to the development of certain Bacillariophyceae species whose the thermal optimum was low (Boumnich et al., 1990). These two factors can explain the prevalence of bacillariophyceae during this period. The bacillariophyceae which are "heavier" tend to sink in periods of low hydrodynamism. So, in Oceanic wind situations which contains the rainy season, cyanophyceae dominated. The water temperatures are more raised and the solar illumination a little weaker. The cyanophyceae which are characterized by thermophiles algae (Sevrin-Reyssac and Pletikosic, 1990) tolerate these high temperatures. In addition, their wide spectre of radiation absorption which is linked to the presence of phycobiliprotein (Briand, 2001), allowed them to use a wide range of sun radiations.

\section{Conclusion}

The climatic variables showed a marked annual pattern following both dominant directions of winds (harmattan and oceanic winds). This annual pattern affected those of the hydrobiological variables. Nutrient concentrations (nitrogen and phosphorus) are generally weak in this central part of the lake. The high vegetable biomass (phytoplankton and macrophyte) observed, immobilize a large part of nutrient. So, the nutrient contribution in quality as in quantity control phytoplankton biomass with dominance of diatomeae (harmattan period) or cyanophyceae (oceanic wind period).

During the period of high winds caused by harmattan situation, resuspension was favored. This situation contributes to increase the transfer of stemmed nutrient to the organic matter mineralization, from the sediment towards the water column. An important part of nutrient is also associated to Saharan dusts (Swap et al., 1992; Goudie and Middleton, 2001), transported in this period by harmattan. These two combined phenomena increase the availability of nutrient for the phytoplanktonic community. The low depth of the lake combined in an important resuspension of particles, contributes to make the water more turbid. However, the resuspension which also assures the transfer of phytoplanctonic cells towards the more euphotic layer opposes to the effect of the brilliant enfeeblement and pull an increase of the primary production.

During low winds period (maritime trade winds) which covers rainy season, contributions of nutrient are essentially constituted by the floods of Senegal River and streaming waters. However, the intensification of rains leaded to a dilution of lake waters, what contributes to the lower concentrations of nutrient. Nutrients transported by river waters were largely immobilized during their transit in the canal of Taoue and in the northern part of the lake by the important populating of floating and fixed macrophytes. During this period, the phytoplanktonic community was dominated by the cyanophyceae as Cylindrospermopsis raciborskii (Ba, 2006), contribute to a lower primary production. These species adopt their flotation to oppose to the sedimentation and they support high temperatures which reign in 
this period. The low phytoplanktonic biomass associated to the low resuspension (Sané, 2006) contributes to increase the water transparency.

\section{COMPETING INTERESTS}

The authors declare that they have no competing interests.

\section{ACKNOWLEDGMENTS}

We would like to thank all members of research unit for their assistance in samples analysis. We also thank Mrs Efimba for her help and advice in many working sessions on this publication. This paper is a contribution to the IRD research group FLAG (UR 098) program, IRD Dakar Senegal.

\section{REFERENCES}

Alpert P, Kaufman YJ, Shay-El Y, Tanre D, Da Silva A, Schubert S, Joseph J.H, 1998. Quantification of dust-forced heating of the lower troposphère. Nature, 395: $367-$ 370.

Arfi R. 2003. The effects of climate and hydrology on the trophic status of sélingué Reservoir, Mali, West Africa. Lakes and Reservoirs: Research and Management, 8: 247-257.

Arfi R, Bouvy M, Cecchi P, Corbin D, Pagano M. 2003. Environnemental conditions and phytoplankton assemblages in two shallow reservoirs of Ivory Coast (West Africa). Arch. Hydrobiol., 156(4): 511-534.

Arfi R, Bouvy M, Cecchi P, Pagano M, Thomas S. 2001. Factors limiting phytoplankton productivity in 49 shallow reservoirs of North Côte d'Ivoire (West Africa). Aquatic Ecosystem Health and Management Society, 4: 123-138.

Ba Ng. 2006. La communauté phytoplanctonique du lac de Guiers (Sénégal): types d'associations fonctionnelles et approches expérimentales des facteurs de régulation. Thèse de doctorat de $3^{\text {ème }}$ cycle en écologie planctonique, UCAD, Dakar, p. 159.
Baijot E, Bouda S, Ouedraogo L. 1994. Etude des conditions physico-chimiques et biologiques des retenues d'eau du Burkina Faso. In Aspects Hydrologiques et Piscicoles des Retenus d'Eau en Zone Soudano-sahélienne, Baijot E, Moreau J, Bouda S (eds). Rapports CTA/CEE Van Ruys-Brussels: 37-64.

Barbosa FAR, Tundisi JG. 1980. Primary production of phytoplankton and environmental characteristics of a shallow quaternary at Eastern Brasil. Arch. Hydrobiol., 90: 139-161.

Barroin G. 1985. La dénitrification en milieu lentique. Rev. Sci. Eau, 4: 79-92.

Boumnich L, Dauta A, Devaux J, Romagoux JC. 1990. Influence de la lumière et de la température sur la croissance de quatre espèces d'algues d'un lac eutrophe (lac d'Aydat, Puy de Dôme, France). Ann. Limnol., 26: 3-10.

Briand JF. 2001. Cyanobactéries toxiques: Prolifération et production toxinique de deux espèces de la région parisienne, Cylindrospermopsis raciborskii et Planktothrix agardhii. Développement d'un bio-essai sur neuroblastomes pour la détection des toxines de type PSP. Thèse de Doctorat du Muséum National d'Histoire Naturelle, Paris, p. 171.

Carl Bro International. 2000. Étude bathymétrique et limnologique du lac de Guiers. Rapport de synthèse. Hydroconsult. International, SGPRE, p. 119.

Carmouze JP, Durand JR, Leveque C. 1983. Lake Chad: Ecology and productivity of a shallow tropical ecosystem. In The Hague. Junk W (ed). Monographiae Biologicae 53, p. 575.

Cogels FX. 1994. La qualité des eaux de surface dans le delta du fleuve Sénégal et le lac de Guiers. Fonds Documentaire ORSTOM, p. 48.

Cogels FX, Gac JY. 1982. Le lac de Guiers : Fonctionnement, Bilans Hydriques évaporation d'une nappe d'eau libre en 
zone sahélienne (Sénégal). Cah. O.R.S.T.O.M., sér. Géol., XII(1): 41-60.

Cogels FX, Thiam A, Gac JY. 1993. Premiers effets des barrages du fleuve Sénégal sur le lac de Guiers. Rev. Hydrobiol. Trop., 26: $105-117$.

Compère P. 1991. Contribution à l'étude des algues du Sénégal. 1. Algues du lac de Guiers et du Bas-Sénégal. Bull. Jard. Bot. Nat. Belg., 61: 171-267.

Dabbadie L. 1996. Etude de la variabilité d'une pisciculture rurale à faible niveau d'intrant dans le Centre-Ouest de la Côte d'Ivoire : Approche du réseau trophique.Thèse Univ. Paris 6, p. 208.

Dia A, Reynaud PA. 1982. Le phytoplancton du lac de Guiers : approche qualitative et quantitative. Cah. ORSTOM, sér. Biol., 45: 35-47.

Gac JY, Coly A, Niang A, Carn M, Cogels FX. 1993. Bilan hydrologique du lac de Guiers en 1992 vers une gestion concertée des crues du fleuve sénégal. Fonds Documentaire ORSTOM, p. 27.

Garnier J. $1989 . \quad$ Peuplement phytoplanctonique et bactéries hétérotrophes d'un lac peu profond (Lac de Créteil, région parisienne) Production, Fonctionnement, Evolution. Thèse de Doctorat d'Etat ès Sciences Naturelles (Ecologie). Université Pierre et Marie Curie, Paris 6, p. 331.

Goldsborough LG, Robinson GGC. 1996. Pattern in wetlands. In Algal Ecology, Freshwater Benthic Ecosystems, Stevenson RJ, Bothwell ML, Lowe RL (eds). Academic Press: San Diego; 77-117.

Goni IB, Fellman E, Edmunds WM. 2001. Rainfall geochemistry in the Sahel region of northern Nigeria. Atms. Environ., 35: 4331-4339.

Goudie AS, Middleton J. 2001. Saharan dust storms: nature and consequences. EarthSci. Rev., 56: 179-204.

Goudie AS, Middleton NJ. 2001. Saharan dust storms: nature and consequences. EarthSci. Rev., 56: 179-204.
Gran G. 1952. Determination of the equivalent point in poten-tiometric titrations, Part II. Analyst, 77: 661-671.

Hasan MR, Mondal MAW, Miah MI, Kibria MG. 2001. Water Quality Study of Some Selected Oxbow Lakes with Special Emphasis on Chlorophyll-a. In Reservoir and Culture-based Fisheries, De Silva SS (ed). Biology and Management, ACIAR Proceed., 98: 126-136.

Holm-Hansen O, Lorenzen CJ, Holmes RW, Strickland JDH. 1965. Fluorimetric determination of chlorophyll. J. Cons. Perm. Int. Explor. Mer., 30: 3-15.

Kalu AE. 1979. The African dust plume: its characteristics and propagation across West African in winter. In Saharan Dust: Mobilisation, Transport and Deposition, Morales C (ed). Wiley: Chichester; 95118.

Khan MA. 1987. Contribution to the Knowledge of freshwater alga of Nigeria.Nova Hedwigia, 44: 473-477.

Labroue J, Toureng JN, Mieussens C, Donville B. 1988. Rôle des lacs de gravière dans la diminution des teneurs en nitrates des aquifères alluviaux de la vallée de la Garonne. Essai de quantification. Annls. Limnol., 24: 31-38.

Langenberg V, Nyamushahu S. 1997. Nutrient Precipitation in the Northern Part of Lake Tanganyika. FAO/FINNIDA Research for th Management of the Fishris for Lake Tanganyika, Rome. No.GCP/RAF/271/FIN-TD/75.

Lavaysse C, Chaboureau J-P, Flamant C. 2011. Dust impact on the West African heat low in summertime. Quart. J. Roy. Meteor. Soc., 137: 118-136, doi: 10.1002/qj.844, 25 juillet 2011.

Lemasson L, Pages J. 1982. Apports de phosphore et d'azote par la pluie en zone tropicale (Côte d'Ivoire). Rev. Hydrobiol. Trop., 15: 9-14.

Lemoalle J. 1973. Azote et phosphore dans les eaux de pluie à Fort Lamy (1970). Cahiers ORSTOM série Hydrobiologie, 7: 95-116. 
Lô HM. 1984. Le bassin de la Gambie en amont de Gouloumbou; contribution à l'hydrologie et à la dynamique fluviales en domaine tropical humide africaine (République de Guinée et du Sénégal). Thèse de $3^{\mathrm{e}}$ Cycle, Univ. Nancy II, p. 396.

Moulin C, Lambert CE, Dulac F, Dayan U. 1997. Control of atmospheric export of dust from North Africa by the North Atlantic Oscillation. Nature, 387: 691-694.

Poole HH, Atkins WRG. 1929. Photo-electric measurement of submarine ilumination through out the year. Journ. Mar. Biol. Assoc., 16: 297-324.

Pourriot R. 1982. Problèmes de stratégies adaptatives. In Ecologie du plancton des eaux continentales. Pourriot R. (ed), Masson Paris : 113-146.

Sané S, Bâ N, Samb PI, Arfi R. 2013. Artificialisation et évolution du statut trophique d'un lac sahélien peu profond : le lac de Guiers (Sénégal). Sécheresse, 24: 64-77. doi : 10.1684/sec.2013.0372

Sane S, Ba N, Samb PI, Noba K, Arfi R, 2015. Moteurs et conséquences de la resuspension dans un lac sahélien peu profond: le lac de Guiers au Sénégal. Int. J. Biol. Chem. Sci., 9(2): 927-943. DOI : http://dx.doi.org/10.4314/ijbcs.v9i2.30
Sané S. 2006. Contrôle environnemental de la production primaire du lac de Guiers, au nord du Sénégal. Thèse de doctorat de $3^{\text {ème }}$ cycle d'écologie planctonique, UCAD, p. 199.

Sarr A, Thiam A, Bâ AT. 2001. Macrophytes et groupements végétaux aquatiques et amphibiens de la basse vallée du ferlo (Sénégal). (AJST) Sciences and Engineering Series, (2)1: 89-97.

Sevrin-Reyssac J, Pletikosic M. 1990. Cyanobacteria in fish ponds. Aquatculture, 88: $1-20$.

Strickland J, Parsons TR. 1972. A pratical hanbook of sea water analysis. Bull. Fish. Res. Bd. Can., 167, p. 311.

Swap M, Garstang M, Greco S, Talbot R, Kallberg P., 1992. Saharan dust in the Amazon Basin. Tellus, 44: 133-149.

Thomas S. 2000. Les différents producteurs primaires d'un petit barrage tropical africain: dynamiques et interactions (Brobo, Côte d'Ivoire). Thèse de Doctorat d'Etat, Université Paris 6, p. 246.

Wetzel RG. 2001. Limnology: Lake and River Ecosystems ( $3^{\text {rd }}$ edn). Academic Press; 1006. 